\title{
Peranan marketing public relations Bukalapak.com dalam mempertahankan brand reputation melalui kegiatan integrated marketing communications
}

\section{Astrid Haryanti*}

Communication Department, Faculty of Economic and Communication, Bina Nusantara University

\section{Siti Dewi Sri Ratna Sari}

Communication Department, Faculty of Economic and Communication, Bina Nusantara University

\begin{abstract}
This study used a qualitative approach with descriptive research by describing each activity of IMC strategy which had been carried out by Bukalapak.com's MPR. The primary data collecting methods used semi structured interviews and non-participant observation. The secondary data used company profile, news from internet and journals. The data method analysis in this study used coding techniques with open coding, axial coding and selective coding. To validate the data, this study used triangulation technique by using the source. The results of this study is the MPR of Bukalapak.com used several integrated marketing communication activities such as advertising, public relations, sales promotions, sponsorship, interactive marketing, direct marketing and personal selling to maintain the brand reputation as a leading e-commerce company in Indonesia.
\end{abstract}

\begin{abstract}
Abstrak
Studi ini menggunakan pendekatan kualitatif dengan jenis penelitian deskriptif melalui penjabaran setiap kegiatan strategi Integrated Marketing Communication (IMC) yang dilakukan oleh MPR Bukalapak.com. Metode pengumpulan data primer menggunakan wawancara semi terstruktur dan obsevasi non partisipan. Data sekunder menggunakan profl perusahaan, berita dari internet dan jurnal. Metode analisis data dalam studi ini menggunakan teknik coding dengan open coding, axial coding dan selective coding. Untuk memvalidasi, studi ini menggunakan teknik triangulasi sumber. Hasil penelitian studi ini menunjukkan MPR Bukalapak.com menggunakan beberapa kegiatan integrated marketing communication seperti periklanan, public relations, sales promotions, pensponsoran, interactive marketing, direct marketing dan personal selling untuk memelihara brand reputation Bukalapak.com sebagai perusahaan ecommerce terkemuka di Indonesia.
\end{abstract}

*Email korespondensi: aharyanti@binus.edu

Pedoman Sitasi: Haryanti, A \& Ratna Sari, S.D.S (2019). Peranan marketing public relations Bukalapak.com dalam mempertahankan brand reputation melalui kegiatan integrated marketing communications. Jurnal Manajemen Strategi dan Aplikasi Bisnis, 2(1), 1-12

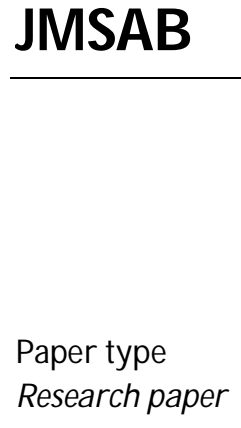

Keywords: marketing public relations, brand reputation, integrated marketing communications

Received: 24 Oct 2018

Accepted: 15 Nov 2018

Online: 06 Feb 2019

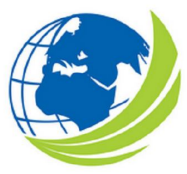

Jurnal Manajemen Strategi dan Aplikasi Bisnis, Vol 2, No.1, April 2019,

pp. 1- 12

eISSN 2655-237X 


\section{PENDAHULUAN}

Perkembangan teknologi yang sangat pesat di era globalisasi ini menyajikan berbagai kemudahan untuk masyarakat melakukan transaksi jual beli secara online. Masyarakat diberikan pilihan untuk menjadi pembeli atau penjual yang dilindungi oleh perusahaan jasa e-commerce sehingga proses jual beli menjadi sangat aman dan mudah. Hanya dalam hitungan menit, konsumen dapat mencari ulasan mengenai bagus atau tidaknya suatu produk yang diminati, membandingkan harga terbaik antara penjual satu dengan yang lainnya dan memutuskan untuk melakukan transaksi. Hanya dalam hitungan hari bahkan jam, barang yang dipesan sudah dapat diterima langsung oleh pembeli dengan berbagai pilihan pembayaran antara lain cash on delivery (COD), transfer rekening ataupun penggunaan kartu kredit yang juga untuk situasi tertentu dapat mengaplikasikan cicilan pembayaran dengan bunga ringan bahkan $0 \%$.

Fenomena kemudahan dalam bertransaksi ini juga membuat persaingan yang ketat antara sesama perusahaan jasa e-commerce, seperti Bukalapak.com, Lazada.com, OLX.com ataupun Berniaga.com. Perusahaan-perusahaan ini berlomba untuk meningkatkan brand awareness untuk menjadi top of mind kategori perusahaan e-commerce di masyarakat. Berbagai aktivitas promosi untuk memperkenalkan dan selalu mengingatkan brand perusahaan dilakukan dimulai dari iklan di berbagai media cetak, online bahkan billboard sampai dengan kerjasama dengan berbagai partner untuk mendapatkan kerjasama yang menguntungkan untuk perusahaan dan konsumen. Penetapan hari khusus untuk belanja online yang jatuh pada tanggal 12 Desember juga menjadi faktor pendorong utama bagi masyarakat untuk berbelanja dengan menikmati potongan harga yang luar biasa.

Bukalapak.com dapat dikatakan sebagai perusahaan jasa e-commerce yang sangat berani dalam memperkenalkan brand kepada masyakarat melalui berbagai media dimulai dengan iklan di media cetak, media online, televisi bahkan billboard pada tahun 2016 lalu. Peranan Marketing Public Relations dalam memulai brand awareness pada tahap awal terkait pengenalan merek atau sering disebut brand activation tidak luput dari kesuksesan brand Bukalapak.com yang sudah cukup bergaung. Proses ini tidak berhenti hanya di sini saja, tetapi bagaimana untuk mempertahankan brand reputation Bukalapak di mata masyarakat khususnya konsumen menjadi fokus penelitian ini. Brand reputation dalam konteks ini berkaitan erat dengan strategi Marketing Public Relations yang dianalisa melalui kegiatan Integrated Marketing Communication yang dilaksanakan oleh Bukalapak.com.

Marketing Public Relations merupakan suatu komponen yang dapat dikatakan proses elaborasi dari bidang Marketing dan Public Relations. Posisi ini menarik untuk dapat dianalisa mengingat perannya di dalam industri untuk brand activation ataupun citra perusahaan sangat bergantung terhadap posisi ini. Tantangan baru yang dihadapi adalah mengetahui kedalaman peranan Marketing Public Relations ini dalam penggunaan komponen Integrated Marketing Communication berupa public relations, interactive marketing, direct marketing, personal selling, sales promotion, sponsorship dan advertising. Sejauh dan sedalam apa peranan Marketing Public Relations ini dalam mempertahankan brand reputation untuk sebuah perusahaan e-commerce menjadi hal menarik untuk dikaji terutama di era teknologi dengan kemajuan dan perubahan proses bisnis yang sangat cepat. Penelitian ini akan sangat menarik karena diperkuat dengan pemilihan Bukalapak.com sebagai perusahaan e-commerce yang dapat dikatakan menduduki salah satu top of mind terkuat dan pemain besar di Indonesia dibandingkan dengan perusahaan sejenis lainnya. Hal ini menjadi salah satu alasan mengapa elemen brand reputation yang akan dipilih sebagai kunci untuk memahami seberapa efektif dan efisien penggunaan IMC tools dalam penelitian ini. Penelitian ini ingin mengungkap proses dan permasalahan yang muncul serta mencoba memberikan solusi atas permasalahan tersebut. Fokus penelitian akan berada pada strategi IMC dan elemen yang digunakan oleh Bukalapak.com sepanjang tahun 2017. 
Penelitian ini bertujuan untuk mendapatkan informasi yang mendalam sebagai berikut: (1) Untuk mengetahui peranan Marketing Public Relations perusahaan e-commerce dalam mempertahankan brand reputation Bukalapak.com; dan (2) untuk mendeskripsikan kegiatankegiatan Integrated Marketing Communication Marketing Public Relations Bukalapak.com dalam mempertahankan brand reputation.

\section{KAJIAN PUSTAKA}

Marketing Public Relations

Marketing Public Relations merupakan perpaduan antara kekuatan public relations dan marketing mix. Istilah Marketing Public Relations pertama kali dipopulerkan oleh Thomas L. Harris melalui bukunya yang berjudul The Marketer's Guide to Public Relations (Ruslan, 2016):

"Marketing Public Relations is the process of planning and evaluating programs that encourage purchase and customer through credible communication of information and impression that identify companies and their products with the needs, concerns of customer."

Dari pernyataan di atas dapat diterjemahkan bahwa Marketing Public Relations adalah sebuah proses perencanaan dan pengevaluasian program yang merangsang penjualan dan pelanggan. Hal tersebut dilakukan melalui pengomunikasikan informasi yang kredibel dan kesan-kesan yang dapat menghubungkan perusahaan, produk dengan kebutuhan serta perhatian pelanggan. Di dalam buku karya Rosady Ruslan (2016) konsep Marketing public Relations Thomas L. Harris tersebut tidak jauh berbeda dengan definisi yang diungkapkan oleh Philip Kotler, yaitu:

"Marketing Public Relations works because it adds value to product through its unique ability to lend credibility to product message."

Dari teori-teori tersebut dapat disimpulkan bahwa program Marketing Public Relations merupakan upaya untuk merangsang (push) pembelian dan sekaligus dapat memberikan nilai-nilai (added value) atau kepuasan bagi pelanggan (statisfied customer) yang telah menggunakan produknya.

\section{Brand (Merek)}

Menurut American Marketing Association (AMA), istilah brand diartikan sebagai nama, istilah, tanda, simbol atau desain atau kombinasi semua hal tersebut yang mengidentifikasikan barang atau jasa satu perusahaan atau kelompok yang membedakan mereka degan simbol kompetitornya (Keller, 2013:117).

Brand merupakan hal utama yang dikenal konsumen, dan dapat menambah nilai dari produk itu sendiri. Hal ini diperkuat dengan bukti bahwa sejumlah konsumen tetap menginginkan suatu brand dan menolak menggantinya walaupun harga produk pengganti lebih rendah. Brand juga dijelaskan sebagai cara-cara untuk menghubungkan perusahaan dengan konsumennya secara emosional, agar mereka tidak tergantikan serta untuk menjalin hubungan yang bersifat seumur hidup (Wheeler, 2009).

Seperti yang telah dijelaskan bahwa brand merupakan sesuatu yang digunakan oleh customer untuk mengidentifikasi barang atau jasa atau kelompok penjual untuk membedakan produk/jasa dari pesaing. Brand tidak hanya berbicara mengenai nama, logo simbol maupun brand elemen lainnya, namun juga berbicara mengenai janji, nilai asosiasi, serta hubungan perusahaan tersebut dengan para konsumennya. 
Reputasi

Kata 'reputasi' berasal dari kata Latin 'reputatio' yang artinya 'menilai' atau 'mengevaluasi'. Dalam kamus Oxford, "reputation" didefinisikan sebagai "the general opinion about a person or a thing" (opini umum tentang seseorang atau sesuatu).

Reputasi merupakan aset korporat terhadap nilai substansial dan terukur. Pandangan bahwa reputasi merupakan aset yang tak terlihat bukan suatu perspektif yang konstruktif menjelaskan mengapa begitu banyak eksekutif perusahaan tidak memiliki ide mengapa reputasi organisasi itu penting atau bagaimana mengelolanya. Namun kemudian terbukti bahwa perusahaan-perusahaan dengan reputasi yang lebih baik menarik lebih para karyawan yang lebih kompeten, mengeluarkan biaya lebih sedikit bagi produk dan layanannya, menambah keuntungan-keuntungan kompetitif yang dapat diukur serta dapat memberikan harga lebih tinggi bagi produk-produk mereka (Doorley \& Garcia, 2010:3).

Charles Fombrun dari New York University mendefinisikan reputasi sebagai SUM dari gambaran yang dimiliki oleh beragam konstituen suatu organisasi. Namun John Doorley dan Fred Garcia (Ibid: 4) menambahkannya menjadi definisi berikut ini:

Reputasi $=$ SUM gambaran $=$ Kinerja + Perilaku + Komunikasi

Dengan demikian menjelaskan bahwa kinerja dan perilaku, seperti halnya komunikasi, merupakan komponen-komponen sangat penting dari reputasi. Pendekatan umum untuk mengukur reputasi suatu organisasi adalah dengan pengukuran komparatif terhadap organisasi yang serupa. HarrisFomburn Reputation Quotient mengevaluasi reputasi di antara "audiens yang berlipat-lipat" menurut 20 atribut yang dikelompokkan ke dalam "dimensi reputasi" yaitu produk dan layanan; kinerja finansial; lingkungan tempat kerja; tanggung jawab sosial; visi dan kepemimpinan; serta daya tarik emosional (Ibid:12-13).

\section{Brand Reputation}

Untuk menjadi sukses dan meningkatkan keuntungan, merek (brand) harus membangun mengembangkan reputasi yang positif. Pembeli biasanya menggunakan nama merek (brand names) sebagai tanda dari kualitas dan nilai serta sering menghubungkannya ke produk dengan nama mereknya untuk menghubungkannya dengan kualitas dan nilai. Nama merek (brand names) sering kali mewakilkan reputasi perusahaan. Performa berkualitas tinggi pada satu produk dapat seringkali ditransfer ke produk lain melaluinama merek (brand names).

Tujuan utama dari merek dan nama merek adalah untuk menyediakan pengguna dengan arti simbolik yang membantu pengguna dalam pengenalan dan proses pengambilan keputusan. Merek seringkali mengembangkan kepribadian mereka sendiri yang memiliki efek pada ya atau tidaknya pengguna memutuskan bahwa citra produk sesuai dengan kebutuhan mereka. Dengan adanya kepribadian ini bisa munculjuga reputasi.

Utama (2007) mengemukakan bahwa reputasi merek merupakan persepsi konsumen tentang pengetahuan mereka terhadap merek dan tanggapan atau pendapat individu lain terhadap merek. Membangun reputasi sebuah merek dapat dikembangkan melalui periklanan dan public relation tapi konsep intinya terletak pada kualitas produk dan kinerja merek.

Pengukuran Brand Reputation dari sudut pandang konsumen atau pelanggan, dapat diukur melalui determinan berikut ini :

1. Kualitas produk. Seberapa baik suatu kualitas produk dan layanan yang diberikan oleh suatu merek terhadap pelanggannya (Utama, 2007).

2. Kinerja merek. Menurut Herbig, et.al (1993) dan Utama (2007), suatu reputasi merk dapat diukur dengan melihat kinerja merek. Apakah merek tersebut dapat menyampaikan kepada pelanggannya apa yang telah dijanjikannya. 
Integrated Marketing Communication

Di tahun 1989, American Association of Advertising Agencies (4 A's) mendefinisikan IMC sebagai "sebuah konsep perencanaan komunikasi pemasaran yang mengakui nilai tambah dari perencanaan komprehensif yang mengkaji peran strategis masing-masing bentuk komunikasi - misalnya iklan, respon langsung, promosi penjualan, dan humas - serta memadukannya untuk meraih kejelasan pesan, konsistensi dan dampak komunikasi maksimal melalui keterpaduan pesan. Sementara Schultz mendefinisikan IMC sebagai proses mengembangkan dan menerapkan berbagai bentuk program komunikasi persuasif dengan pelanggan dan calon pelanggan dari waktu ke waktu. Tujuan IMC adalah untuk mempengaruhi atau memberi dampak secara langsung perilaku audiens komunikasi yang terseleksi.

Kotler dan Armstrong (2004) mendefinisikan IMC sebagai konsep dimana suatu perusahaan secara hati-hati mengintegrasikan serta mengkoordinasikan saluran-saluran komunikasinya untuk menyampaikan pesan yang jelas, konsisten serta memiliki daya tarik tentang organisasi dan produkproduknya.

Pada akhirnya, IMC adalah tentang perencanaan dengan tujuan menyampaikan sebuah pesan yang konsisten. IMC yang efektif harus mendorong hubungan pelanggan yang kuat, tetapi hal itu dilakukan melalui perencanaan efektif dengan tujuan untuk mengembangkan sebuah program komunikasi terintegrasi yang akan mengoptimalkan tujuan-tujuan komunikasi yang spesifik dan akan membawa pada perilaku yang diinginkan pada audiens target.

Tujuan Integrated Marketing Communication

Tujuan IMC adalah untuk menciptakan sinergi, yang artinya bahwa mengkoordinasikan alat-alat komunikasi pemasaran lebih berdampak dibandingkan bila alat-alat tersebut tidak dikoordinasikan.

Integrasi menjanjikan efisiensi, memelihara kesetiaan pelanggan dan juga mendukung konsistensi dalam program pemasaran secara total. Koordinasi serta integrasi seluruh alat-alat komunikasi pemasaran, jalan serta sumber dalam suatu perusahaan menjadi sebuah program mulus yang memaksimalkan dampak atas konsumen serta pengguna akhir dengan biaya minimal (Kotler \& Armstrong, 2004:467).

Peran Integrated Marketing Communication dalam Membangun Brand (Merek)

Komunikasi pemasaran merupakan setiap kontak antara merk dan pasar. Hal ini berarti lebih dari periklanan dan promosi yang sederhana. Ini berarti segalanya: kemasan, bagian luar kendaraan yang membawa produk perusahaan, sales kit untuk perdagangan, kartu-kartu bisnis, pensponsoran, plang nama toko, dan lain-lain. Inilah yang menyebabkan IMC menjadi sangat penting dalam membangun brand (merk) yang sukses. Manajemen merk harus mengkoordinasikan semua aspek dari komunikasi merk, menjamin pesan yang konsisten. Yang dimaksud dengan sebuah merk (brand) adalah sesuatu yang 'terikat pada suatu obyek untuk memberikan informasi tentang obyek tersebut.'Konsep merk melampaui 'nama atau merk dagang khususnya', memberikan informasi tentang dirinya sendiri yaitu makna. Jika makna ini berkembang dari waktu ke waktu, sebagai hasil dari komunikasi pemasaran merk. IMCyang efektif menjamin kontrol atas makna ini.

Elemen Integrated Marketing Communication

Menurut Philip Kotler dan Kevin Lane Keller (2009), terdapat 12 elemen yang membentuk "Roda Komunikasi Pemasaran" yaitu advertising (periklanan), public relations, sales promotions (promosi penjualan), point of purchase, packaging (kemasan), exhibition (pameran), sponsorship (pensponsoran), internet (interactive marketing), direct marketing (pemasaran langsung), personal selling (penjualan pribadi), corporate identity (identitas korporat), word of mouth. Dalam penelitian ini, hanya 7 elemen yang akan digunakan sebagai konsep untuk meneliti yaitu advertising (periklanan), public relations, sales promotions (promosi penjualan), sponsorship (pensponsoran), 
internet (interactive marketing), direct marketing (pemasaran langsung) dan personal selling (penjualan pribadi).

\section{Marketing Public Relations

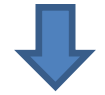

\section{Kegiatan Integrated Marketing Communication:}

1. Advertising (Periklanan)

2. Public Relations

3. Sales Promotions (Promosi Penjualan)

4. Sponsorship (Pensponsoran)

5. Internet (Interactive Marketing)

6. Direct Marketing (Pemasaran Langsung)

7. Personal Selling (Penjualan Pribadi)

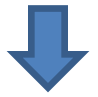

\section{Mempertahankan Brand Reputation}

\section{Gambar 1. Kerangka Model Penelitian}

\section{METODE PENELITIAN}

Penelitian dilakukan dengan menggunakan wawancara semi terstruktur kepada dua narasumber dan observasi non-partisipan di Bukalapak.com. Narasumber utama dari penelitian ini adalah Corporate Communication Manager dari Bukalapak.com yang diwawancarai secara tatap muka langsung di kantor Bukalapak.com yang berlokasi di Jalan Ampera Raya No. 22, Cilandak, Jakarta Timur. Narasumber kedua adalah informan ahli untuk mengukur keabsahan data dari narasumber pertama yang diwawancarai melalui Skype pada tanggal 23 November 2017 karena berdomisili di Makassar.

Pendekatan Penelitian

Pendekatan yang dilakukan dalam penelitian ini adalah pendekatan kualitatif. Penelitian kualitatif menggunakan metode yaitu pengamatan, wawancara atau penelaahan dokumen. Jenis penelitian yang digunakan pada penelitian ini adalah jenis deskriptif. Data yang dikumpulkan dalam penelitian ini banyak mengambil bentuk kata-kata atau gambar daripada angka-angka dan juga memaparkan realitas yang ada dan dibandingkan dengan landasan teori pada bab sebelumnya sehingga jenis penelitian deskriptif sesuai untuk penelitian ini. Metode penelitian yang digunakan pada penelitian ini menggunakan studi kasus. Dikatakan oleh Kriyantono (2014) studi kasus adalah metode riset yang menggunakan berbagai seumber data (sebanyak mungkin data) yang bisa digunakan untuk meneliti, menguraikan, dan menjelaskan secara komprehensif berbagai aspek individu, kelompok, suatu program, organisasi atau peristiwa secara sistematis.

\section{Teknik Pengumpulan Data}

Teknik pengumpulan data merupakan suatu cara yang digunakan untuk memperoleh data pada penelitian ini memakai teknik pengumpulan data primer dan sekunder. Data primer adalah data yang didapatkan dari sumber pertama dan dari tangan pertama di lapangan. Menurut Istijanto 
(2009) data primer adalah data asli yang dikumpulkan oleh periset untuk menjawab masalah risetnya secara khusus. Dalam penelitian ini, data primer dikumpulkan melalui dua cara, yaitu wawancara semi terstruktur dan obeservasi non partisipan. Penelitian ini menggunakan metode wawancara semi terstruktur yang dilakukan kepada dua orang informan, yaitu Corporate Communication Manager Bukalapak.com dan informan ahli. Wawancara semi terstruktur dipilih karena dalam melakukan wawancara dapat memberikan pertanyaan, namun dapat memberikan pertanyaan bebas yang masih terkait dalam pembahasan penelitian sesuai dari jawaban dari sumber. Pada penelitian ini juga dilakukan observasi non partisipan dikarenakan pengamat tidak terjun langsung di dalam melakukan kegiatan IMC di Bukalapak.com dalam mempertahankan brand reputation.

Data sekunder adalah data yang diperoleh dari tangan kedua atau bisa dibilang dari sumber kedua. Menurut Istijanto (2009) data sekunder merupakan data yang telah dikumpulkan oleh pihak lain, bukan oleh periset sendiri untuk tujuan yang lain. Data sekunder dalam penelitian ini berupa dokumentasi dan portofolio kegiatan divisi Corporate Communication Bukalapak.com dalam mempertahankan brand reputation mereka.

Teknik Analisis Data

Menurut Mudjiarahardjo (dalam Sujarweni, 2014) teknik analisis data adalah sebuah kegiatan untuk mengatur, mengurutkan, mengelompokkan, memberi kode atau tanda, dan mengkategorikannya sehingga diperoleh suatu temuan berdasarkan fokus atau masalah yang ingin dijawab. Melalui serangkaian aktivitas tersebut, data kualitatif yang biasanya berserakan atau bertumpuk-tumpuk bisa disederhanakan untuk akhirnya bisa dipahami dengan mudah. Setelah data berkumpul selanjutnya dianalisis. Analisis data kualitatif sangat sulit karena tidak ada pedoman buku, tidak berproses secara linier, dan tidak ada aturan-aturan yang sistematis. Teknik yang digunakan dalam analisis data penelitian ini ialah coding. Menurut Strauss dan Corbin (dalam Ardianto, 2011) analisis data kualitatif khususnya dalam penelitian Grounded Theory, terdiri atas tiga jenis pengodean (coding) utama, yaitu pengodean terbuka (open coding), pengodean berporos (axial coding), pengodean selektif (selective coding). Coding adalah membaca ulang seluruh material wawancara dan mendapatkan garis besar atau gambaran umum hasil wawancara. Topik dipisahkan berdasarkan kategorinya sesuai tujuan riset, setelah itu baru menganalisisnya (Ardianto, 2011).

Uji Keabsahan Data

Untuk mengetahui validitas sebuah penelitian diperlukan uji keabsahan data. Teknik keabsahan data yang digunakan pada penelitian ini yaitu jenis trustworthiness yang secara spesifik menggunakan triangulasi sumber. Melalui teknik ini dapat melakukan perbandingan atau mengecek ulang data informasi yang didapat dengan dari narasumber dan membandingkan dengan data yang didapat secara umum. Dengan begitu, peneliti mengetahui mana yang sebenarnya terjadi.

\section{HASIL DAN PEMBAHASAN}

Bukalapak.com didirikan oleh Achmad Zaky dan Nugroho Herucahyono dengan semangat memajukan UKM Indonesia. Mereka memulai usaha di sebuah rumah indekos dan berupaya meyakinkan para UKM bergabung di Bukalapak.com satu demi satu. Tahun 2011 Bukalapak.com memiliki 5 orang karyawan dan mengelola 10.000 UKM yang telah tergabung. Pada tahun 2012 Jumlah UKMyang tergabung meningkat menjadi 50.000 UKM.

Bukalapak.com membentuk komunitas UKM sebagai wadah untuk berbagi informasi sukses berjualan online. Bukalapak.com terus melakukan inovasi dalam hal pengembangan platform yang berbasis mobile apps sehingga pada tahun 2014 Bukalapak.com resmi meluncurkan aplikasi belanja berbasis online versi Android dan pada tahun 2015 mereka berhasil meluncurkan aplikasi berbasis 
iOS. Pada tahun 2016 Bukalapak.com meluncurkan program "Pahlawan" dengan misi memberdayakan UKM di seluruh Indonesia. Bukalapak menandatangani kesepakatan bersama dengan Badan Ekonomi Kreatif (BEKRAF) dalam upaya pemberdayaan potensi ekonomi kreatif Indonesia. Jumlah karyawan Bukalapak mencapai 500 orang dan jumlah UKM yang bergabung melampaui 1.000.000 UKM dan terus bertambah.

Hasil penelitian ini didapatkan setelah wawancara dilakukan kepada narasumber utama yaitu Corporate Communication Manager Bukalapak.com dan narasumber ahli untuk mengukur keabsahan data dari jawaban narasumber utama serta observasi non-partisipan di Bukalapak.com. Berdasarkan konsep Marketing Public Relations dari Thomas L. Harris peran Corporate Communication sebagai Marketing Public Relations Bukalapak.com adalah sebagai berikut:

a. Mempertahankan reputasi di mata khalayak tentang produk perusahaan:

Bukalapak.com telah membangun awareness pelanggan dengan cara selalu memberikan servis yang baik dan melakukan promosi terkait dengan promo-promo di situs baik Youtube dan media sosial yang dikemas secara menarik dan kreatif. Hal tersebut dilakukan untuk mempertahankan brand reputation mereka sebagai perusahaan yang kreatif dan inovatif.

b. Memberi informasi dan edukasi seputar produk:

Bukalapak.com selalu memberikan informasi terkait dengan kegiatan dan promo apa saja yang ada di Bukalapak. Informasi tersebut dapat dilihat dari spanduk, brosur dan media sosial serta iklan di Youtube dan TV.

c. Menciptakan susasana harmonis antara konsumen dan produk serta perusahaan.

Bukalapak.com selalu memberikan servis yang baik kepada pelanggan dengan cara menyediakan layanan live chat guna menampung dan mengatasi keluhan ataupun masukan yang diberikan. Menurut dari hasil wawancara dengan Corporate Communication Manager, divisi Marketing Public Relations Bukalapak.com telah melakukan sebuah proses perencanaan dan pengevaluasian program yang merangsang penjualan dan pelanggan, yaitu dengan cara mengadakan acara-acara setiap bulannya, berbagai promosi, konsep pemasaran yang unik dan berbagai publikasi untuk merangsang pengunjung untuk berbelanja di Bukalapak.com. Event yang dilakukan setiap momentum tertentu merupakan cara Bukalapak.com untuk menarik pembeli.

Menurut narasumber utama Ibu Evi Andriani selaku Corporate Communication Manager bahwa Bukalapak.com sering mengadakan event seperti Buka Talk untuk para pelapak dan media gathering serta kegiatan lainnya. Promosi yang dilakukan Bukalapak.com menggunakan media cetak, media elektronik dan media sosial, namun Bukalapak.com lebih menonjol di internet dan media sosial karena Bukalapak mempunyai target konsumen generasi $\mathrm{X}$ yang mempunyai beragam media sosial seperti Facebook, Instagram, Twitter, Path, dan Pinterest serta sering mengakses internet setiap harinya.

Kegiatan-kegiatan Integrated Marketing Communications yang dilakukan oleh Marketing Public Relations Bukalapak.com sebagai perusahaan e-commerce untuk mempertahankan brand reputation berfokus pada 7 (tujuh) kegiatan yaitu advertising (periklanan), public relations, sales promotions (promosi penjualan), sponsorship (pensponsoran), interactive marketing (pemasaran interaktif), direct marketing (pemasaran langsung) dan personal selling (penjualan langsung).

Periklanan adalah semua bentuk berbayar dari presentasi non pribadi dan promosi ide, produk atau layanan oleh sponsor yang teridentifikasi (Kotler, 2004: 494). Kegiatan advertising (periklanan) yang dilakukan oleh Bukalapak.com adalah dengan menggunakan advertising below the line (BTL) dan above the line (ATL) di banyak media baik itu televisi, media sosial (Youtube, Facebook dan Instagram), serta media cetak. Iklan yang dibuat oleh Bukalapak.com berisi mengenai penawaran produk baik seperti potongan harga, atau bebas ongkos kirim. Tujuan periklanan adalah tugas komunikasi spesifik yang harus dipenuhi dengan audiens target yang spesifik selama periode waktu yang spesifik pula. Dalam hal ini Bukalapak menargetkan generasi X yang berkarakteristik menyukai hal-hal yang kreatif dan berbau teknologi. 
Kegiatan public relations yang dilakukan adalah dengan membuat program Buka Talks. Buka Talks adalah ajang untuk sharing session ke sesama pengguna Bukalapak, biasanya diadakan di hari spesial seperti Sumpah Pemuda, Kebangkitan Nasional dan Hari Kemerdekaan. Tujuan dari kegiatan ini adalah untuk menciptakan value sekaligus menciptakan brand image yang kreatif dan inovatif. Kegiatan ini biasanya diadakan pada momen tertentu seperti memperingati hari sumpah pemuda dan hari bersejarah lainnya.

Public Relations memiliki tiga peran utama untuk dimainkan dalam bauran komunikasi: pembangunan dan pemeliharaan niat baik korporat; kesinambungan bagi dukungan produk yang baik; serta melalui hal ini, pembangunan dan pemeliharaan hubungan yang sesuai:

a. Peran tradisional dalam menciptakan niat baik serta menstimulasi minat antar organisasi dengan berbagai khalayak kuncinya. Tugasnya adalah untuk menyediakan serangkaian isyarat yang bisa dikenali oleh khalayaknya, memahami serta memposisikan organisasi yang bisa membangun reputasi kuatnya. Peran ini terikat dengan strategi korporat serta maksud dari komunikasi yang strategis. Dalam hal ini Corporate Communication Bukalapak.com yang berperan sebagai Public Relations mengemas pesan-pesan mengenai perusahaan dan event promosi yang menarik untuk dipublikasikan kepada media. Diharapkan pesan yang ingin disampaikan dapat diterima dengan baik oleh khalayak luas.

b. Peran public relations adalah untuk mendukung pemasaran produk dan layanan organisasi, dan tugasnya adalah untuk mengintegrasikannya dengan elemen-elemen lain dari bauran komunikasi pemasaran. Public Relations dan periklanan memiliki peran tambahan. Pesan yang disampaikan oleh PR melalui siaran pers mereka mampu mengenalkan bahkan membangun kepercayaan masyarakat untuk percaya dengan brand dari Bukalapak.com itu sendiri. Dengan terciptanya kepercayaan pembeli terhadap brand Bukalapak.com maka akan terciptanya loyalitas yang nantinya mendukung proses pemasaran produk yang dijual di Bukalapak.com.

c. Perannya untuk menyediakan cara untuk membangun hubungan. Untuk melakukan ini, public relations memiliki tanggung jawab untuk mendorong interaksi serta dialog untuk menyediakan cara melalui interaksi, ceramah dan diskusi dapat dilakukan untuk memainkan bagian penuh dari proses komunikasi serta pesan yang disampaikan, didengarkan, dipertimbangkan serta dilaksanakan. Peran yang ketiga ini diaplikasikan oleh PR Bukalapak.com dengan mengadakan media gathering, media visit, dan press conference, guna mengenalkan Bukalapak.com kepada media dan masyarakat luas. Selain itu, dengan memberikan penghargaan dan hadiah pada momen tertentu mampu membuat hubungan yang tercipta terbina dengan baik.

Untuk kegiatan sales promotions (promosi penjualan) yang dilakukan oleh Bukalapak.com adalah dengan diskon hari belanja online nasional (harbolnas), biasanya diadakan pada tanggal 11 bulan November, namun pelaksanaannya dilakukan oleh divisi Marketing. Selain itu juga dengan memberikan kode voucher yang berisi potongan harga atau diskon, maupun referral code yang digunakan oleh pembeli pada saat berberlanja di Bukalapak.com nantinya.

Kegiatan sponsorship (pensponsoran) yang dilakukan Bukalapak.com salah satunya adalah dengan menjadi pembicara yang diadakan di berbagai acara perguruan tinggi. Sedangkan kegiatan dari interactive marketing yang dilakukan oleh Bukalapak.com adalah melalui telepon, email, dan live chat yang terakhir diperuntukkan bagi pelapak yang kemungkinan terdapat keluhan dari pelanggan. Adapun kegiatan direct marketing (pemasaran langsung) yang dilakukan oleh pihak Bukalapak.com adalah dengan menggunakan media social, e-mail dan live chat guna menstimulus penjualan.

Khusus untuk kegiatan terakhir yakni personal selling atau penjualan langsung tidak dilakukan oleh MPR Bukalapak.com karena masuk ke dalam ruang lingkup Marketing. Namun di sini mereka menyediakan platform live chat yang diperuntukkan bagi pelapak (penjual) dengan pembeli agar bisa berkomunikasi langsung apabila terjadi keluhan dan sebagainya. Diosi Budi Utama (2007) mengemukakan bahwa reputasi merek merupakan persepsi konsumen tentang pengetahuan mereka terhadap merek dan tanggapan atau pendapat individu lain terhadap merek. Membangun 
reputasi sebuah merek dapat dikembangkan melalui periklanan dan public relations tapi konsep intinya terletak pada kualitas produk dan kinerja merek. Hal inilah yang selalu dipegang teguh oleh Bukalapak.com untuk mempertahankan brand reputation mereka harus memperhatikan setiap aktivitas atau kegiatan yang dilakukan oleh divisi marketing public relations harus menarik dan inovatif. Hal tersebut sudah diaplikasikan oleh pihak Bukalapak.com dalam setiap promosi di iklan, maupun setiap kegiatan public relations dengan cara membuat siaran pers yang menarik perhatian yang dibuat ke dalam bentuk komik yang menarik.

Pengukuran Brand Reputation dari sudut pandang konsumen atau pelanggan, dapat diukur melalui determinan berikut ini :

a. Kualitas produk: seberapa baik suatu kualitas produk dan layanan yang diberikan oleh suatu merek terhadap pelanggannya. Kualitas produk yang diberikan oleh Bukalapak.com yang dijual oleh pelapak sangat diperhatikan karena akan mempengaruhi kepercayaan konsumen mereka. Selain itu apabila kualitas produk meeka di luar harapan pembeli maka Bukalapak.com akan mengganti produk yang sudah dibeli.

b. Kinerja merek: menurut Herbig, et.al (1993) dan Utama (2007), suatu reputasi merk dapat diukur dengan melihat kinerja merek. Apakah merek tersebut dapat menyampaikan kepada pelanggannya apa yang telah dijanjikannya. Bukalapak.com selalu memperhatikan kinerja mereka dengan selalu memperhatikan kualitas dan tingkat kepercayaan konsumen pada setiap transaksi yang dilakukan.

\section{KESIMPULAN}

Dari hasil penelitian yang telah dilakukan mengenai Peranan Marketing Public Relations Bukalapak.com sebagai perusahaan e-commerce dalam mempertahankan brand reputation melalui kegiatan Integrated Marketing Communication yang berfokus pada periode 2017, maka diperoleh kesimpulan sebagai berikut:

\section{Kesimpulan}

Ruang lingkup Corporate Communications yang ada di Bukalapak.com menjadi beberapa bagian yaitu SEO, tim research dan tim Public Relations. Setiap bagian mempunyai peran masing-masing, seperti contoh tim research bertugas melihat tren sekarang dan perspektif masyarakat terhadap Bukalapak.com supaya terus adaptif. Sedangkan peran Marketing Public Relations yang merupakan divisi di bawah naungan divisi Marketing adalah menciptakan kredibilitas yang baik di mata masyarakat.

Kegiatan-kegiatan Integrated Marketing Communications Bukalapak.com berfokus pada 7 (tujuh) kegiatan yaitu advertising (periklanan), public relations, sales promotions (promosi penjualan), sponsorship (pensponsoran), interactive marketing (pemasaran interaktif), direct marketing (pemasaran langsung) dan personal selling (penjualan langsung) yang dilakukan oleh Marketing Public Relations Bukalapak.com dapat mempertahankan brand reputation sebagai perusahaan e-commerce terkemuka di Indonesia.

Pada kegiatan Public Relations yang dilakukan adalah dengan membuat program Buka Talks, yaitu ajang untuk sharing session ke sesama pengguna Bukalapak.com dan biasanya dilaksanakan pada momen tertentu atau hari bersejarah. Selain itu mereka juga melakukan program media relations dengan mengadakan kegiatan media visits dan press conference secara teratur. Untuk kegiatan sales promotions (promosi penjualan) yang dilakukan oleh Bukalapak adalah dengan Diskon hari belanja online nasional (harbolnas), biasanya diadakan pada tanggal 11 bulan November, namun pelaksanaannya dilakukan oleh divisi Marketing. Selain itu juga dengan memberikan kode voucher yang berisi potongan harga atau diskon, maupun referral code yang digunakan oleh pembeli pada saat berberlanja di Bukalapak.com nantinya. Kegiatan sponsorship (pensponsoran) yang dilakukan Bukalapak.com salah satunya adalah dengan menjadi pembicara di berbagai acara perguruan tinggi. Sedangkan kegiatan dari interactive marketing yang dilakukan oleh Bukalapak.com adalah melalui 
Jurnal Manajemen Strategi dan Aplikasi Bisnis, 2(1), 1-12

Haryanti, A \& Ratna Sari, S.D.S. Peranan marketing public...

telepon, email, dan live chat yang terakhir diperuntukkan bagi pelapak yang kemungkinan terdapat keluhan dari pelanggan. Adapun kegiatan direct marketing (pemasaran langsung) yang dilakukan oleh pihak Bukalapak.com adalah dengan menggunakan media social, e-mail dan live chat guna menstimulus penjualan. Khusus untuk kegiatan terakhir yakni personal selling atau penjualan langsung tidak dilakukan oleh MPR Bukalapak.com karena masuk ke dalam ruang lingkup Marketing.

Implikasi Praktis dan Sarans

Diharapkan dengan adanya penelitian ini dapat berguna bagi pihak yang akan melakukan penelitian dengan topik yang serupa, namun dengan topik mengukur keberhasilan dari peranan MPR yang dilakukan dan mengukur keefektivitas dari fungsi MPR yang dijalankan. Berdasarkan kesimpulan dan pembahasan yang dilakukan dengan melihat kenyataan di lapangan maka ada beberapa saran yang perlu diperhatikan: Pertama, marketing Public Relations perlu berperan serta dalam perumusan serta pelaksanaan riset-riset yang terkait dengan branding perusahaan dan tidak sekedar menerima hasil dari divisi Riset. Dengan demikian akan mempermudah untuk merencanakan berbagai kegiatan Integrated Marketing Communication yang dapat mempertahankan brand reputation Bukalapak.com sebagai salah satu perusahaan e-commerce terkemuka di Indonesia. Kedua, mencari kegiatan Integrated Marketing Communication alternatif selain yang sudah dilakukan oleh Bukalapak.com seperti mensponsori acara-acara yang terkait dengan dunia teknologi informasi dan komunikasi, mengikuti pameran, mengadakan acara-acara yang langsung berinteraksi dengan konsumennya, dan lain-lain.

\section{REFERENSI}

Ardianto, E. (2011). Metodologi Penelitian untuk Public Relations Kuantitatif dan Kualitatif. Bandung: Simbiosa Rekatama Media.

Arief, M. (2007). Pemasaran Jasa \& Kualitas Pelayanan. Malang: Bayumedia.

Arikunto, S. (2010). Prosedur Penelitian Suatu Pendekatan Praktik.

Belz, A. (2011). The McGraw-Hill 36 Hours Course: Product Development. California: McGraw-Hill .

Crawford, M., \& Benedeto, A. D. (2006). New Product Management, 8th Edition. New York: McGraw-Hill.

Creswell, J. W. (2010). Research Design Pendekatan Kualitatif,. Kuantitatif, dan Mixed. Yogyakarta: Pustaka Pelajar.

Davis, D. F., Golicic, S. L., \& Marquardt, A. (2009). Measuring brand equity for logistics services. The International Journal of Logistics Management, 20(2), 201-212.

Doorley, John, Garcia, \& Fred H. (2015). Reputation Management: The Key to Sucessful Public Relations and Corporate Communication, 3rd Ediiton. New York: Routledge.

Effendy, O. U. (2007). Ilmu Komunikasi (Teori dan Praktek). Bandung: PT. Remaja Rosdakarya.

Ferrinadewi, E. (2008). Merek \& Psikologi Konsumen; Implikasi pada Strategi Pemasaran. Jakarta: Graha Ilmu.

Gazpers, V. (2007). Lean Six Sigma for Manufacturing and Service Industry. Jakarta: PT. Gramedia Pustaka.

Herbig, P., \& Milewicz, J. (1995). The relationship of reputation and credibility to brand success. Journal of consumer marketing, 12(4), 5-11.

Hoffmann, C., \& Weithaler, L. (2015). Building Brand Reputation in the Digital Age: Identifying effective brand communication to win the moment of truth online.

Iriantara, Y. (2008). Media Relations Konsep, Pendekatan, dan Praktik. Bandung: Simbiosa Rekatama Media. Istijanto, 2009. Aplikasi Praktis Riset Pemasaran. Jakarta : Gramedia Pustaka utama

Keller, K. L. (2013). Strategic Brand Management, 4th Edition. Pearson Education.

Knox, S., \& Freeman, C. (2006). Measuring and managing employer brand image in the service industry. Journal of Marketing Management, 22(7-8), 695-716.

Kotler, P., \& Armstrong, G. (2012). Principles of Marketing, 14th Edition. Pearson Education.

Kotler, P., \& Keller, K. L. (2009). Manajemen Pemasaran Jilid 1. Jakarta: Erlangga.

Kotler, P., Armstrong, \& Gary. (2004). Principles of Marketing, 10th Edition. Pearson/ Prentice Hall.

Kotler, P., Armstrong, \& Gary. (2012). Principles of Marketing, 6th Edition. Pearson Education Limited. 
Kotler, Philip, Keller, Kevin Lane. (2009). Marketing Management, 13 th Edition. Pearson Education, Inc.

Kriyantono, R. (2006). Teknik Praktis Riset Komunikasi: Disertai Contoh Praktis Riset Media, Public Relations, Advertising, Komunikasi Organisasi, Komunikasi Pemasaran. Jakarta: Kencana Prenada Media Group.

Lestari, E., \& Maliki. (2006). Komunikasi yang Efektif.Jakarta: Lembaga Administrasi Negara RI.

Mikáčová, L., \& Gavlaková, P. (2014). The role of public relations in branding. Procedia-Social and Behavioral Sciences, 110, 832-840.

Newsom, D., Turk, J., \& Kruckerberg, D. (2013). This is PR: The Realities of Public Relatons. USA: Cangage Learning.

Nova, F. (2011). Crisis PR: Strategi PR dalam Mengahadpi Krisis, Mengelola Isu, Membangun Citra dan Reputasi Perusahaan. Jakarta: PT. Rajagrafindo Persada.

Nurjaman, K., \& Umam, K. (2012). Komunikasi dan Public Relations. Bandung: Pustaka Setia.

Prindle, Ron. 2011. A Public Relations Role in Brand Messaging. Washington

Ruslan, R. (2012). Manajemen Public Relations \& Media Komunikasi. Jakarta: Rajawali Pers.

Ruslan, R. (2013). Metode Penelitian Public Relations dan Komunikasi. RajaGrafindo Persada.

Ruslan, R. (2016). Manajemen Public Relations dan Media Komunikasi. Jakarta: RajaGrafindo Persada.

Saladin, D. (2007). Manajemen Pemasaran. Bandung: Linda Karya.

Schiffman, Leon G. (2014). Consumer Behavior. 11 th Edition. Boston: Pearson Education.

Seitel, Fraser P., Doorley, John. (2012). Rethinking Reputation: How PR Trumps Marketing and Advertising in The New Media World. New York: Palgrave Macmillan.

Sitinjak, T. (2005). Stratefi Menaklukan Pasar Melalui Riset Ekuitas dan Perilaku Merek. Jakarta: PT. Gramedia Pustaka Utama.

Soemirat, S., \& Ardianto, E. (2010). Dasar-Dasar Public Relations. Bandung: PT. Remaja Rosdakarta.

Sugiyono. (2012). Metode Penelitian Kuantitatif, Kualitatif, dan R\&D. Bandung: Alfabeta.

Sujarweni, W. (2014). Metodologi Penelitian . Yogyakarta: PUSTAKA BARU PRESS.

Surachman, S. A. (2008). Dasar-dasar Manajemen Merek. Malang: Bayumedia Publishing.

Tjiptono, F. (2011). Service, Quality and Satisfaction. Yogyakarta: ANDI Yogyakarta. . (2008). Strategi Pemasaran. Yogyakarta: ANDI Yogyakarta.

Utama, D. B. (2007). Membangun Merek, Membentuk Kepercayaan Konsumen dan Menciptakan LoyalitasMerek. Jurnal. Telaah Manajemen, 2(2), 122-133.

West, R., \& Turner, L. H. (2008). Pengantar Teori Komunikasi Analisis dan Aplikasi. Jakarta: Salemba Humanika.

Wheeler, A. (2009). Designing Brand Identity: An Essential Guide for The Entire Branding Team (3rd edition). New Jersey: John Wiley \& Sons.

Wu, P. C., Yeh, G. Y. Y., \& Hsiao, C. R. (2011). The effect of store image and service quality on brand image and purchase intention for private label brands. Australasian Marketing Journal (AMJ), 19(1), 30-39.

Yamit, Z. (2005). Manajemen Kualitas Produk dan Jasa. Jakarta: Ekonisia.

\section{PROFIL PENULIS}

Astrid Haryanti adalah dosen Communication Department Fakultas Ekonomi dan Komunikasi Universitas Bina Nusantara dengan pengalaman mengajar Integrated Marketing Communication, Customer Relationship Management, Event Management, PR and Branding di tingkat sarjana. Penulis memiliki ketertarikan pada penelitian marketing public relations dan brand reputation. Astrid Haryanti adalah penulis koresponden dapat dihubungi di: aharyanti@binus.edu

Siti Dewi Sri Ratna Sari adalah dosen Communication Department Fakultas Ekonomi dan Komunikasi Universitas Bina Nusantara dengan pengalaman mengajar komunikasi pemasaran seperti Integrated Marketing Communication, Customer Relationship Management, Event Management, PR and Branding, Public Relations Advertising, Corporate PR Writing and Advertorial in Global Sector, Corporate Reputation Management, Issues and Crisis Management di tingkat sarjana dan pascasarjana. Penulis memiliki ketertarikan pada penelitian marketing public relations dan brand reputation. 